\title{
Polyphasic approach and adaptative strategies of Nostoc cf. commune (Nostocales, Nostocaceae) growing on Mayan monuments
}

\author{
M. Ramírez ${ }^{\mathrm{a}, \mathrm{b}}$, M. Hernández-Marinéa ${ }^{\mathrm{a}}$ P. Mateo ${ }^{\mathrm{c}}$, E. Berrendero ${ }^{\mathrm{c}}$ \& M. \\ ROLDÁN $^{\mathrm{d}}$
}

${ }^{a}$ Facultat de Farmàcia, Unitat de Botànica, Universitat de Barcelona, 08028 Barcelona, Spain

${ }^{b}$ Posgrado en Ciencias Biológicas, Universidad Nacional Autónoma de México

'Departamento de Biología, Facultad de Ciencias, Universidad Autónoma de Madrid, 28049 Madrid, Spain

${ }^{d}$ Servei de Microscòpia, Universitat Autònoma de Barcelona, Edifici C, Facultat de Ciències, 08193 Bellaterra, Spain

\begin{abstract}
An aerophytic Nostoc, from a Mayan monument, has been characterized by phenotypic and molecular approaches, and identified as a morphospecies of Nostoc commune. Phylogenetic analysis indicates that it belongs to a Nostoc sensu stricto clade, which contains strains identified as $N$. commune. Nostoc cf. commune is found in two close areas: Site I (protected from direct sunlight by a wall), where it forms biofilms on mortar with Trentepohlia aurea; and Site II, where it grows on exposed stucco with the accompanying organism Scytonema guyanense. Over the year, in a habitat dictated by alternating wet and dry seasons, the organisms vary in appearance. Its life cycle comprises two seasonally-determined developmental stages (growth during the wet season and dormancy during the dry season) and two transitional stages (preparation for the dry season, and rehydration and recovery). At the beginning of the wet season the resistant stages from the previous dry season are rehydrated and form propagula, that adopt a colonial shape surrounded by a gelatinous sheath. As conditions become drier, clearly more in Site II, $N$. cf. commune employs adaptative strategies agains the drought, such as reducing the number of cells inside thick ensheathed colonies. Akinetes were observed, although only in Site II and in cultures of an isolated strain. Their fine structure shows parallel arrays of whorled thylakoids and septal intercellular connections. Spectral confocal laser scanning microscopy was used to analyze the fluorescence spectra of the photosynthetic pigments. $N$. cf. commune shows phycocyanin, allophycocyanin and chlorophyll $a$ in both sites. Moreover, spectra of vegetative ensheathed cells, collected at Site II at the dry season, differed in their fluorescence spectrum: they feature a peak at $564 \mathrm{~nm}$, attributed to phycoerythrin, which increases cell tolerance against the detrimental effects of strong light. These findings indicate that both the distribution and persistence of $N$. cf. commune might stem from cumulative adaptative strategies that increase its resistance to extreme desiccation.
\end{abstract}

Key words: Adaptative strategies, biofilms, cellular differentiation, confocal, cyanobacteria, Nostoc, phycobilins, phylogenetic relationships, subaerial, taxonomy, ultrastructure

\section{Introduction}

Species of the genus Nostoc are conspicuous components of terrestrial microbial populations worldwide (DodDs et al. 1995), represented by roughly 60 recognizable (plus many unclear ones) morphospecies and strains (KOMÁREK 2010). Nostoc commune VAucher ex BORNet et FlaHAULt is especially widespread globally (Роттs 2000; Wright et al. 2001; Novis \& SMISSEN 2006). Its persistence and success in terrestrial environments have been attributed to its ability to tolerate desiccation after an extended drought period, and to rapidly rehydrate and recover metabolic activity once favorable conditions have been reestablished (DodDs et al. 1995; PотTs 2000; FuKUdA et al. 2008).

Local environmental conditions (e.g. availability of water) strongly influence the complex life cycle of $N$. commune, determining the presence and sequence of phases as well as the differentiation of specialized cells (MOLLENHAUER 1988). Adaptation to drying and subsequent recovery of physiological capacities and active growth upon rehydration require protection of cell components and repair processes. Responses to drying and rewetting include: changes in the glycan layer, which protects and provides a repository for 
water (Hill et al. 1997; РотTs 2000; TAmaru et al. 2005); induction of photoprotective pigments, carotenoids and external ultraviolet light (UV) (Garcia-Pichel \& Castenholz 1991; EhlingSchulz et al. 1997); accumulation of non-reducing dissacharides, such as trehalosa, to stabilize drying cells (Billi \& PotTs 2002; SaKamoto et al. 2009); preservation of cell fine structure and cellular integrity during desiccation and upon rehydration (Peat \& Potts 1987); and deactivation of PSII with diminution of photosynthesis and loss of PSI activity and dissipation of light energy absorbed by pigment-protein complexes (ARÁOZ \& HÄDER 1999; SATOH et al. 2002; Hirai et al. 2004; FUKUDA et al. 2008). As light-harvesting pigments, cyanobacteria contain chlorophyll $a$, carotenoids and phycobiliproteins: phycoerythrin (PE, $\lambda_{\mathrm{em}} \sim$ $575 \mathrm{~nm}$ ), phycocyanin $\left(\mathrm{PC}, \lambda_{\mathrm{em}} \sim 645 \mathrm{~nm}\right)$ and allophycocyanin (APC, $\lambda_{\mathrm{em}} \sim 658 \mathrm{~nm}$ ) (KERÄNEN et al. 1999, Wolf \& SCHÜSSLER, 2005). The energy transfer between these pigments can be influenced by environmental factors such as temperature and light intensity (Wen et al. 2005; KuMAR \& MURTHY 2007). In addition to the absorption properties of the screening pigments the acclimation processes involve modulation of light harvesting apparatuses in function of light quality and intensity and nutrient availability (VenUgopal et al. 2006). The emission spectrum of photosynthetic organisms reflects their pigment composition and indicates its energy transfer pathways (STRASSER \& BUTLER 1977).

We observed and isolated ensheathed colonies from Mayan monuments exhibiting Nostoc morphology, in an area of contrasting wet and dry seasons (Bonampak, Chiapas, Mexico).
We identified the field material and the cultured strain as a morphospecies of Nostoc commune (Geitler 1932; KomÁreK \& ANAGNostidis 1989; Mollenhauer et al. 1994). Herein we report on the characterization, based on phenotypical, ecological and molecular data, with the aim of establishing if and how environmental conditions affect morphology and pigment composition and to determine life cycle stages.

\section{Material and Methods}

Site description and sample collection. The archeological site Bonampak was declared a Natural Monument in 1992 by the Mexican National Commission of Protected Natural Areas (CONANP). Bonampak is located in the Mexican state of Chiapas, $\left(16^{\circ} 42^{\prime} 14^{\prime \prime} \mathrm{N}, 91^{\circ} 03^{\prime} 54^{\prime \prime} \mathrm{W}\right)$. The region is tropical, with heavy rainfall from August to November and a dry season from December to April (http://smn.cna. gob.mx/emas/).

Biofilms of Nostoc cf. commune were collected at Bonampak in January 2008, two months after the beginning of the dry period and in August 2008, two months after the beginning of the wet period, from two sites on the building walls. Site I (Fig. 1) was protected from direct sunlight by a wall, and Site II (Fig. 2) was exposed to direct sunlight. At Site I the main biofilmaccompanying organism was Trentepohlia aurea (L.) MARTIUS and the substratum was limestone and mortar, whereas at Site II, Scytonema guyanense (Mont.) Born. et FlaH. thrived on stucco.

The moisture and temperature of the biofilm surfaces were measured with a Surveymaster BLD 5360 protimeter (General Electric, USA) (Table 1). Small flakes and splinters of substrata were collected from both sites. The samples were divided into aliquots that were either preserved dry in silica gel, observed

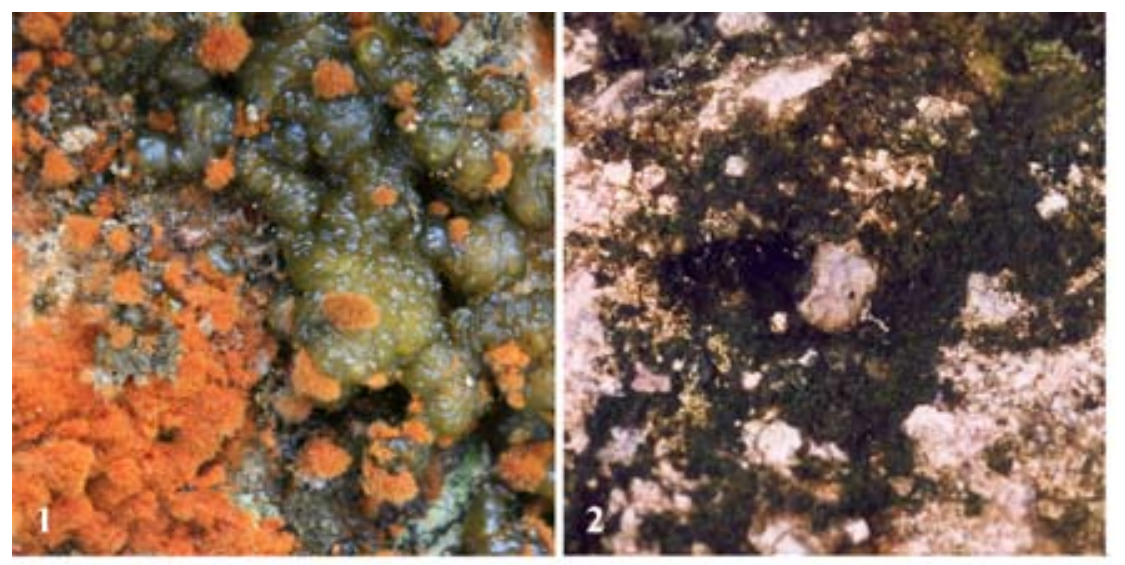

Figs 1-2. Detail of the sampling Sites in Bonampak (Chiapas, México): (1) site I, protected from direct sunlight. Wet season. Mortar with tough green colonies of $N$. cf. commune, accompanied by Trentepohlia aurea. (2) Site II, exposed to direct sunlight. Stucco with blackened dry flakes of $N$. cf. commune accompanied by Scytonema guyanense. 
directly by light microscopy, or fixed for confocal laser scanning microscopy (CLSM). The preserved, dry materials were cultured (starting 28 January, 2010 using 1\% solidified BG11 medium (STANIER et al. 1971) and incubated in subdued daylight (west-facing window) at room temperature.

Light microscopy. The samples were visualized using an Axioplan microscope (Carl Zeiss, Oberkochen, Germany) equipped with an MRc5 AxioCam photomicrographic system. Cell measurements were made based on the optical images from field and cultured material. Characteristics previously considered as taxonomically important at generic and specific levels were considered (FRÉMY 1930; Geitler 1932; KANTZ \& Bold 1969; KomÁReK \& AnAGNOSTIDIs 1989).

Confocal laser scanning microscopy (CLSM). Samples were observed either live (cultures) or fixed (field material) with $3 \%$ paraformaldehyde in $0.1 \mathrm{M}$ PBS and $60 \mathrm{mM}$ saccharose. Images were captured with a Leica TCS-SP5 CLSM (Leica Microsystems Heidelberg GmbH, Mannheim, Germany) using Plan-Apochromatic 63x (NA 1.4, oil) objectives with different zoom ranges. Chlorophyll $a$ and phycobiliproteins emitted at 650 to $790 \mathrm{~nm}$ (excitation: $561 \mathrm{~nm}$ ) and were visualized in the red channel. The structure of the colony was evaluated using the XYZ mode of the CLSM microscope, acquiring optical sections in XY planes. Three-dimensional images were captured every $0.25 \mu \mathrm{m}$ with a 1 Airy unit confocal pinhole. Stacks were subsequently processed with Imaris v. 6.1.0 software (Bitplane AG Zürich, Switzerland) to obtain maximum intensity projections (RoldÁn et al. 2004a).

The pigments of the material were identified in field samples and in various cultured samples using a lambdascan function of CSLM, fluorescence-based method that enables three-dimensional localization of the phototrophic microorganisms and simultaneous analysis of the fluorescent pigments from a single cell (RoLDÁn et al. 2004b). The field samples were mounted on Mat-Teck culture dishes (Mat Teck Corp., Ashland, Massachusetts, United States), and the cultured samples, onto microscope slides and examined with the same confocal microscope using a Plan-Apochromatic $63 x$ (NA 1.4, oil) objective ( $2 x$ zoom). Series of images $(\mathrm{xy} \lambda)$, called lambdastacks, were taken to determine the spectra emission of photosynthetic pigments and to establish their maxima. The excitation wavelength used was the $488 \mathrm{~nm}$ line of an Ar laser. The emission detection was set from 515 to $775 \mathrm{~nm}$ and optimal confocal pinhole. For each xy focal plane, confocal microscopy measured the emission variation every 15 $\mathrm{nm}$ (lambda step size $=7.5 \mathrm{~nm}$ ). The emission spectra analysis was processed using Leica LAS AF. A Region of Interest (ROI) was delimited to determine the mean fluorescence intensity (MFI) in the selected area versus the emission wavelength. To analyze cells, 15 ROIs
Table 1. Temperature and relative humidity in the sampling sites at the time of sample collection.

\begin{tabular}{clcc}
\hline $\begin{array}{l}\text { Sampling } \\
\text { site }\end{array}$ & Material & BT $\left({ }^{\circ} \mathrm{C}\right)$ & BRH (\%) \\
\hline \multirow{2}{*}{ I } & Limestone and & (w) 26 & 97 \\
& mortar & (d) 23 & 54 \\
\multirow{2}{*}{ II } & Stucco & (w) 29 & 45 \\
& & (d) 26 & 32 \\
\hline
\end{tabular}

W=wet season, 08.08.2008; d=dry season, 17.01.2008;

$\mathrm{BT}=$ biofilm temperature; $\mathrm{BRH}=$ biofilm relative humidity.

of $1 \mu \mathrm{m}^{2}$ were selected in the thylakoid region; MFI and maxima were calculated in these ROIs. The mean and standard error were calculated for all the ROIs examined.

Transmission electron microscopy (TEM). Cultured material was fixed in a mixture of glutaraldehyde $(2.5 \%)$ in $0.1 \mathrm{M}$ cacodylate buffer and post fixed in $1 \% \mathrm{OsO}_{4}$ in the same buffer. They were then dehydrated with acetone and embedded in Spurr resin. Ultrathin sections were stained with $2 \%$ uranyl acetate and lead citrate. The sections were examined using a JEOL 1010 TEM at $100 \mathrm{kV}$ accelerating voltage.

Isolation of DNA, PCR amplification and sequencing. Genomic DNA from dried field samples was extracted and amplified following a modification of the procedure described by BERRENDERO et al. (2008). Samples were frozen in liquid nitrogen. The DNA was extracted using the UltraClean Microbial DNA isolation Kit (MoBio Laboratories, Lab Conda S.A.). The $16 \mathrm{~S}$ rRNA gene was amplified using the primers pA (5'-AGAGTTTGATCCTGGCTCAG-3') (EDWARDS et al. 1989) and cyanobacteria-specific B23S (5'-CTTCGCCTCTGTGTGCCTAGGT-3') (LePĖRe et al. 2000). Polymerase chain reaction was performed in a Perkim-Elmer GenAmp PCR System 2400. The PCR reactions were conducted in $25 \mu \mathrm{l}$ volumes and contained $10 \mathrm{pmol}$ of each primer, $6 \mu \mathrm{l}$ of DNA extraction, $200 \mu \mathrm{M}$ dNTP, $1 \mu \mathrm{g}$ BSA, $1.5 \mathrm{mM}$ $\mathrm{MgCl}_{2}, 2.5 \mu \mathrm{l}$ of $10 \mathrm{x}$ polymerase buffer, $5 \mu \mathrm{l}$ Eppendorf Taqmaster PCR-enhancer, $0.75 \mathrm{U}$ Ultratools DNA polymerase (Biotools). The PCR comprised an initial denaturation step at $94{ }^{\circ} \mathrm{C}$ for $5 \mathrm{~min}$; three cycles at $94{ }^{\circ} \mathrm{C}$ for $45 \mathrm{sec}$ each; one, at $57^{\circ} \mathrm{C}$ for $45 \mathrm{sec}$; one, at $68{ }^{\circ} \mathrm{C}$ for $2 \mathrm{~min}$; and one, at $68{ }^{\circ} \mathrm{C}$ for $7 \mathrm{~min}$ (Gkelis et al. 2005). The concentration of amplified products was checked on $1.5 \%$ agarose gel. The PCR products were cloned into the pGEM $^{\mathrm{R}}-\mathrm{T}$ Easy Vector Systems (PROMEGA) and transformed into competent $E$. coli. The products were purified using the Real Clean Spin Kit (REAL). The 16S rRNA gene was sequenced with Big Dye Terminator v3.1 Cycle Sequencing kit and ABI Prism 3730 Genetic Analyzer (Applied Biosystems), according to the manufacturer's 
Table 2. Median value and range of morphometrical characteres considered to be of taxonomic importance at generic and specific levels for Nostoc cf. commune. Vegetative cells length and width: from field material (dry and wet season) (FMD, FMW), rewetted material (RM), cultured material (CM) and "Coccoid cells" (Ccc). Posthormogonial cells length and width from RM and CM. Akinetes length and width from FMW and CM. n=50.
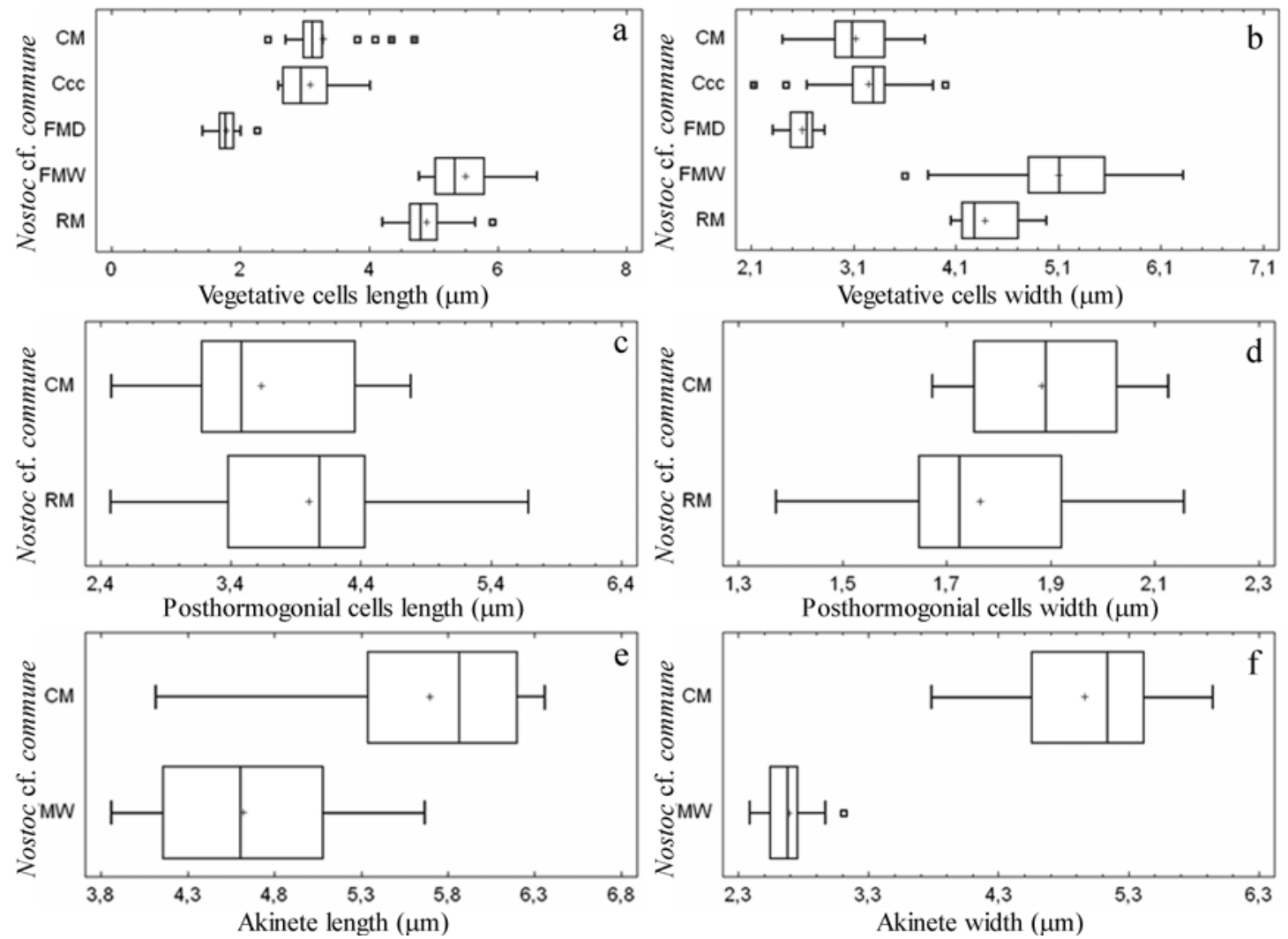

instructions. The sequences were obtained for both strands independently.

Phylogenetic analysis. Nucleotide sequences obtained from DNA sequencing were compared with sequence information available in the National Center for Biotechnology Information database using BLAST (http://www.ncbi.nlm.nih.gov/BLAST). Multiple sequence alignment was performed using CLUSTALW (THOMPSON et al. 1994) of the current version of the BioEdit program (HALL 1999). The alignment was later visually checked and corrected with BioEdit. Trees based on the 16S rRNA gene were constructed using the neighbour joining (NJ) (SAITOU \& NEI 1987), maximum parsimony (MP), and maximum likelihood (ML) methods. NJ and MP were constructed using the MEGA 4 program (TAMURA et al. 2007), while ML was inferred using PhyML software (http://atgc.lirmm.fr/ phyml/) (Guindon \& GAScuEl 2003). Distances for the NJ tree were estimated by the algorithm of TAJIMA \& NEI (1984) model; nucleotide positions containing gaps and missing data were initially retained for all such sites in the analyses, and then excluded as necessary in the pairwise distance estimation (pairwise deletion option). Maximum parsimony was performed with the close-neighbour-interchange search algorithm with random tree addition; missing information and

alignment gap sites were treated as missing data in the calculation of tree length. Bootstrap analysis of 1,000 replicates was performed for NJ and MP trees. For ML, the general time-reversible model (GTR) was selected, assuming a discrete gamma distribution with four categories of site-to-site variability of change (gamma shape parameter: 0.168 ) with the nearest-neighbourinterchange algorithm, using 100 bootstrap samples. Similarity values were calculated using the web-based tool EzTaxon (www.eztaxon.org). The nucleotide sequences obtained in this work have been deposited in the GenBank database (Fig. 21).

\section{Results}

Morphology and life cycle. The field life cycle of $N$. cf. commune encompasses four distinct phases, which are coupled to climatological events: development during the wet season; preparation for drying; survival from dessication; and rewetting combined with increasing the number of propagula.

The morphometric results of vegetative cells, poshormogonial cells and akinetes are shown 

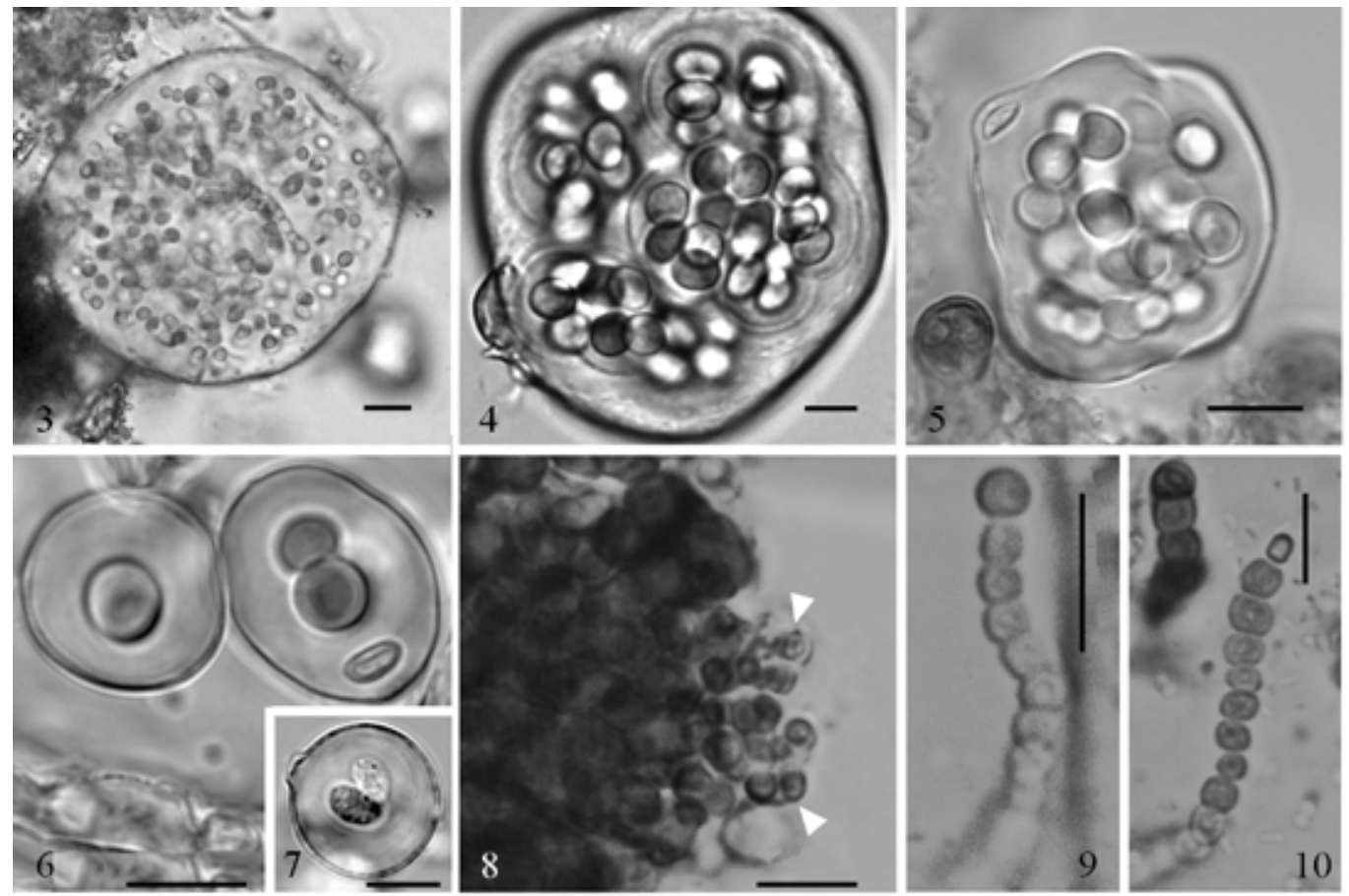

Figs 3-10. Microphotographs of Nostoc cf. commune, Site II: (3) wet season. Filaments inside the colonial sheath. (4) Transition to the dry season. Small colonies with layered sheaths inside the mother colony. (5-6) Ensheated coccoid cells. (7) Ensheated granulated akinetes. (8-10) Two years old reweted material. (8) Colonies with tightly packed contorted trichomes, built by large spherical or irregular cells, and thin trichomes (arrow) released by disintegration of the outer layer of the sheath. (9-10) Post -hormogonial filaments bearing terminal heterocytes. Scale bars $10 \mu \mathrm{m}$.

in Table 2. During the wet season the thalli of the $N$. cf. commune from the two Sites were similar. They comprised conspicuous agglomerations of olive-green colonies, with swollen sheaths covering clusters of seriate filaments entangled to different degrees (Fig. 3; Table 2a, b). During the transition to the dry season, the colonies shrank and the cells formed layered sheaths surrounded by a pellicle (Figs 4-7). These colonies contained groups of cells in the aseriate stage or, in colonies from Site II, even just one or two single cells per colony, called coccoid cells (ABDELAHAD \& BAZICHELLI 1989). The few remaining cells were bigger than those from the wet season. At Site I, in the dry season, the thalli were strongly attached to other components of biofilms and to the substrata, whereas at Site II, they were friable, dry blackgreen flakes. Ensheathed ellipsoidal akinetes (Fig. 7; Table 2e, f) were observed once at Site II.

After rewetting two year old material from Site II, the thalli comprised irregularly shaped colonies, surrounding tightly ensheated contorted filaments, composed of large spherical or irregular cells. During the first two weeks, disintegration of colonies released hormogonial filaments (Fig. 8). Post-hormogonial filaments comprised barrel- shaped cells with terminal heterocytes (Figs 9-10; Table 2c, d).

The results (Table 2 ) showed little variability of measured cell size, except for coccoid cells (Table 2a, b).

The only cultures that survived were those grown from dry season samples taken from Site II. Four weeks into growth, blue green vegetative filaments developed, comprising thin, elongated cells. This later fully differentiated into vegetative filaments with diversely sized round or barrel-shaped cells. Aseriate stages were also present. The sheath covering these trichomes was colorless, and neither diffluent nor layered. No heterocytes were observed. Within six months, akinetes formed: these had smooth colorless to yellowish epispore, were oblong to barrel-shaped, and larger than the vegetative cells (Fig. 11; Table 2e, f). The akinetes germinated, producing chains of small, oblong cells, which emerged from the open akinete wall. All growth stages (germinating akinetes, post-hormogonial cells, vegetative cells and chains of akinetes) coexisted in a single Petri dish, under the same culture conditions (Fig. 12).

Pigments. Upon excitation at $488 \mathrm{~nm}$, living $N$. cf. commune cells gave overlapping 

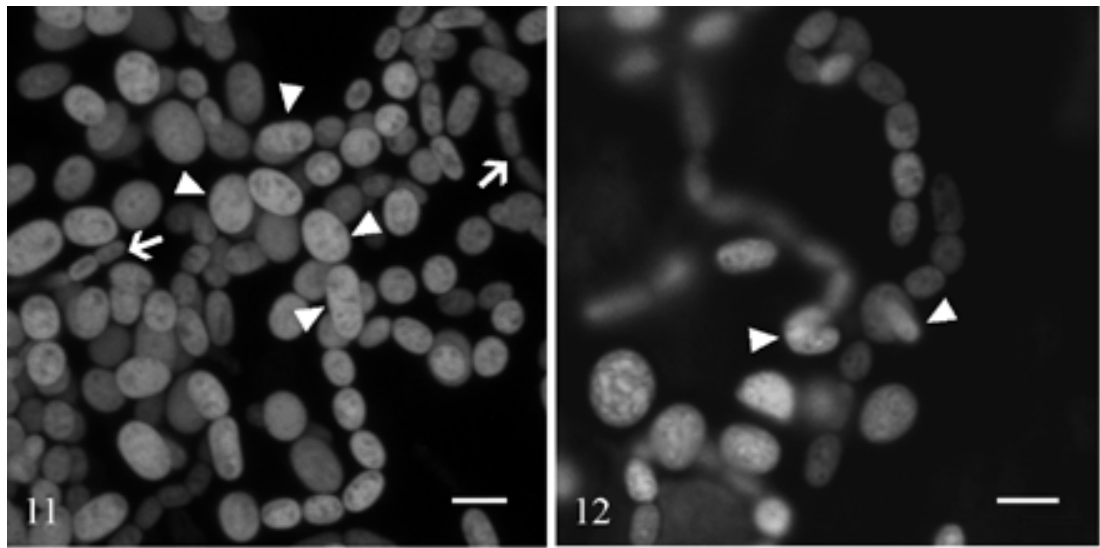

Figs. 11-12. Confocal images: (11) projection of the general view of cultured material: post-hormogonial (head arrow), seriate and aseriate filaments and chain of akinetes (arrow). (12) Germinating akinetes. Single section of hormogonia emerging from the akinete envelope (arrow). Scale bars $10 \mu \mathrm{m}$.

fluorescence emission spectra. Fig. 13 shows lambda scans of vegetative cells of several sizes of field samples collected from Site I (Fig. 14) and from Site II (Fig. 15).

Vegetative cells from Site I had a peak at $645 \mathrm{~nm}$ and a plateau from 645 to $654 \mathrm{~nm}$. In this case, small peaks at $686 \mathrm{~nm}$ and $717 \mathrm{~nm}$ were observed. In contrast to vegetative cells growing in Site I (protected from light), the cells from Site II (exposed to light) showed two clear maxima, at $564 \mathrm{~nm}$ and $654 \mathrm{~nm}$. There were also shoulders at $686 \mathrm{~nm}$ and $717 \mathrm{~nm}$.

The fluorescence maximum in the spectrum of cells from cultured material had a broad emission peak at $661 \mathrm{~nm}$ with shoulders at 651 $\mathrm{nm}$ and $678 \mathrm{~nm}$; no clear peak or shoulder was identified at $684 \mathrm{~nm}$, the maximum for chlorophyll $a$. The position of maximum emission for each cell varied slightly with cell size or growth state (data not shown), but did show any clear trend. The fluorescence spectra from Site I and cultured material did not exhibit any intrinsic differences except for lower mean fluorescence intensity (MFI) in field samples. However, the maximum at $564 \mathrm{~nm}$ was only observed in samples from the dry season at Site II (Fig. 13).

TEM. The multilayered cell wall was surrounded by a sheath that was either nonlamellated or slightly lamellated, and nondiffluent (Figs. 16-20). Fibrils and vesicles, located close to the cell wall and apparently liberated from it, contributed to sheath formation. Chains of elongated post-hormogonial cells had thylakoids located peripherally or distributed parietaly, with whorls pushing through the center (Fig. 16). Larger vegetative cells, mostly rounded, featured thylakoids distributed throughout the cell with nucleoid spaces containing large trapezoidal carboxisomes (Figs. 17-18). Akinetes featured a thick external layer, storage of endogenous polyglucoside granules, and cyanophycin granules (a multi-L-arginyl-poly-L-aspartate peptide) distributed throughout (Fig. 19). However, no black spots, characteristic of lipid deposits, or poly-b-hydroxybutyrate granules were observed. Cross walls were formed by centripetal growth (Fig. 20). The cells were held together, forming trichomes. The septa between some older vegetative cells were crossed by intercellular connections (Fig. 20), although the plasma membrane was discontinuous throughout these gaps.

Phylogenetic analysis. The 16S rRNA sequence data of field samples of Nostoc cf. commune were obtained from three individual clones. The almost complete sequence (1460$1462 \mathrm{bp}$ ) was determined for two clones, and near complete sequence data (1141 bp) was obtained for the third clone. We detected microheterogeneities among 16S rRNA sequence determined from individual clones (sequence similarity of 99.4-99.5\%), probably related to multiple copies of 16S rRNA operon (BOYER et al. 2001). The phylogenetic trees were built using NJ, MP and ML methods. Since similar clustering was obtained by the three methods, we represented the NJ tree with the indication of bootstrap values for the three approaches (Fig. 21). Our sequences clustered into a well-defined group with high bootstrap support containing strains of $N$. commune, $N$. punctiforme, N.calcicola, lichen phycobionts as well as other soil and rivers representatives of Nostoc with 

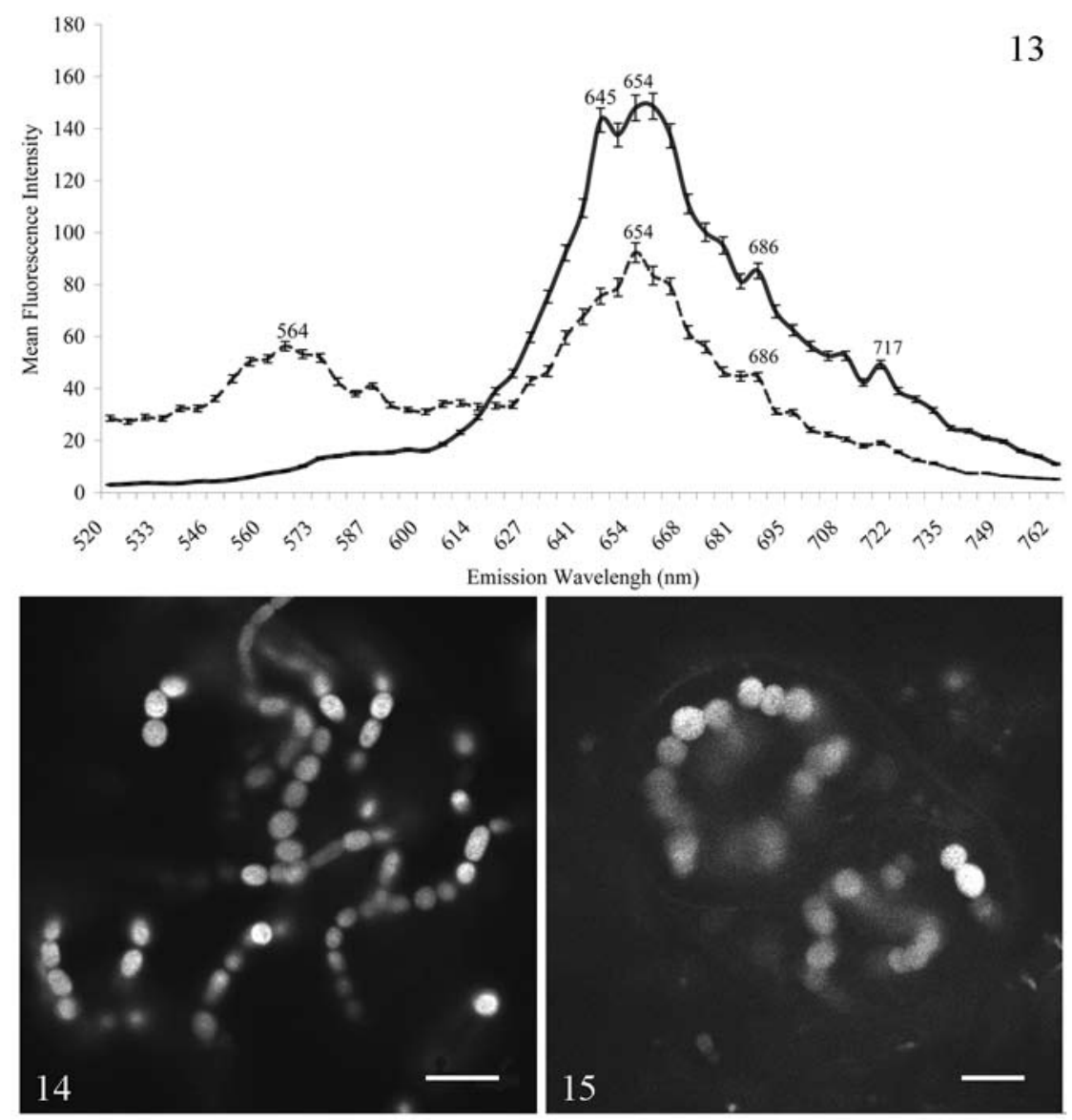
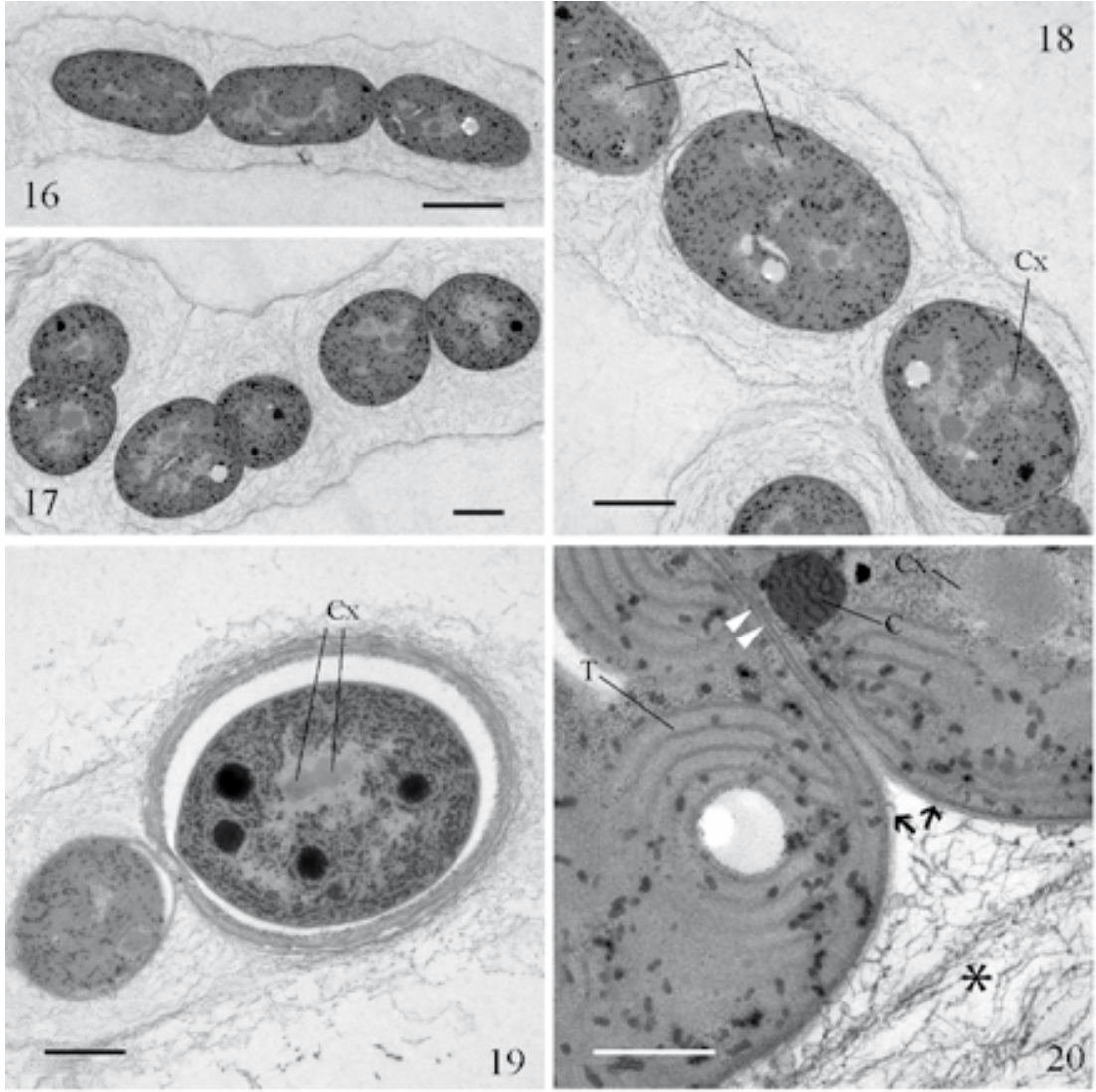

Figs 13-15. Lambda scans of vegetative cells from field material: (13) spectral profile representing mean fluorescence intensity versus emission wavelength $\quad(515-775 \quad \mathrm{~nm})$ for single cells of Nostoc cf. commune at Site I and Site II (excitation wavelength $=488$ nm). Peaks at 645 and 654 $\mathrm{nm}$ from phycocyanin and allophycocyanin, respectively, and at 686 from chlorophyll $a$. Site I (thick line). Site II (dotted line). In addition, the maximum at 564 from phycoerythrin. Data are the mean \pm standard error from the different sample examined. (14-15) Confocal scanning laser microscopy images corresponding to the maxima emission signal of photosynthetic pigments (14) Site I. (15) Site II. Scale bar 10 $\mu \mathrm{m}$.
Figs 16-20. TEM micrographs of cultured material: (16) elongated post-hormogonial cells with near-peripheral thylakoids. (17) Aseriate vegetative filaments. (18) Mature vegetative filaments with thylakoids distributed throught the whole cell. (19) Glancing section of a vegetative cell and akinete. (20) Longitudinal section of a vegetative cell through the septum showing intercellular connections (white head arrows), continuous outer layer (black head arrows) and fibrilar sheath (asterisk). N, nucleoid areas $\mathrm{C}$, cyanophycin granule; $\mathrm{Cx}$, carboxisome; $\mathrm{T}$, thylakoids. Scale bar $1 \mu \mathrm{m}$ (Figs 16-19); scale bar $0.2 \mu \mathrm{m}$ (Fig. 20). 
sequence similarity ranging from 96.4 to $100 \%$ (Table 3).

\section{Discussion}

Field samples and the cultured material have been included in the form-species $N$. commune (WRIGHT et al. 2001) according to phenotypic and ecological criteria (Frémy 1930; GeITLER 1932; Kantz \& Bold 1969; Mollenhauer 1988; KomÁreK \& ANAGnostidis 1989; Mollenhauer et al. 1994; Novis \& SMISSEN 2006). Nearly all the forms seen in the field were observed in cultured material, except for tough colonies and coccoid cells.

Stages in the life cycle of the genus Nostoc depend on environmental conditions (KANTZ \& Bold 1969; Mollenhauer 1988; KomÁrek \& Anagnostidis 1989; Mollenhauer et al. 1994; Dodds et al. 1995; PotTs 2000; Wolf \& SCHÜsSLER 2005). Changes in in morphology, cell structure (ROLDÁN et al. 2006), and external sheaths or deposits are coupled to physiological changes. Mass formation of akinetes and subsequent hormogonia development, observed in the cultured sample, occur very rarely in the field, as reported for N. commune (Geitler 1932; KantZ \& Bold 1969; ABDELAHAD \& BAzZichelli 1989). Formation of akinetes is not the only mechanism to ensure persistence of cyanobacterial populations. Indeed, the rarity of akinetes in Bonampak, where $N$. cf. commune is subject to regular cycles of desiccation and rewetting, indicates that other persistent forms exist. Isolated or double cells, surrounded by a thick extracellular matrix, have been found and cited repeatedly with different names: cocci, young spores, unicellular hormogonium or coccoid cells (ABDELAHAD \& BAZICHELli 1989). Reducing the number of cells inside each colony, down to only one coccoid cell, surrounded by a thick complex sheath enables some cells to survive. The abundance of these cells, suggests that they are a drought- resistant form that can overcome the dry season (DodDs et al. 1995; РотTs 2000; SATOH et al. 2002; Hirai et al. 2004; TAMARU et al. 2005; FuKUDA et al. 2008).

Spectral detection in confocal microscopy enables in vivo fingerprinting of the photosynthetic pigments in a single cell (from thick intact samples). The type and spatial localization of pigments can then be correlated to the cell type (RoLDÁn et al. 2004a). Lambda scans of vegetative cells correlated well with published spectra of extracted pigments (ONG \& GLAZER 1988) and in vivo pigments, using similar tools and conditions (ROLDÁN et al. 2004b; Wolf \& SCHÜSSLER 2005). The emission peaks and the shape of the spectra varied slightly with sample state due to environmental conditions. In these samples, the fluorescence peaks at $645 \mathrm{~nm}$ and $654 \mathrm{~nm}$, always present, were assigned to PC and APC, respectively (KERÄNEN et al. 1999). Furthermore, chlorophyll $a$ was clearly seen at the emission wavelengths of $678 \mathrm{~nm}$ and $686 \mathrm{~nm}$ (KERÄNEN et al. 1999; Wolf \& SchüsSLER 2005; Kumar \& MurThy 2007). In the field material, the emission spectra of both PC and APC also have a shoulder above $720 \mathrm{~nm}$ (KERÄNEN et al. 1999). Samples from Site II exhibited lower PC fluorescence $\left(\lambda_{\mathrm{em}} \sim 645 \mathrm{~nm}\right)$ than those from Site I, indicating that energy transfer from phycobilisomes to the photosystems was suppressed in the former (KumAR \& MuRThy 2007). The fluorescence spectra of ensheathed vegetative $N$. cf. commune cells, collected at Site II in the dry season, differed from those of samples collected at Site I and those of cultured material-namely, in showing a peak at $564 \mathrm{~nm}$, which was attributed to $\mathrm{PE}$ (Bordowitz \& MONTGOMERY 2010). Although Sites I and II are very close (less than $50 \mathrm{~m}$ apart), the biofilms at Site I (for example, those with Trentepohlia aurea) are subject to less extreme conditions. Striking changes in the fluorescence properties - and therefore, presumably in the synthesis of PE by vegetative cells, in lightexposed habitats during the dry season - could be an adaptation to high irradiation energies and protection from photodamage of PSII, given that much of the energy absorbed by PE is lost as fluorescence (ARÁOZ \& HÄDER 1999; FUKUDA et al. 2008). Factors that may affect PE production, such as developmental stage-specific changes in pigment composition (MilLIE et al. 2002; Wolf \& SCHÜSSLER 2005), were ruled out upon comparison of vegetative cells and akinetes. The production of PE, is another strategy which increases cell tolerance against the detrimental effects of strong

Fig. 21. Neighbour-joining phylogenetic tree based on analysis of 16S rRNA genes showing the position of the sequences obtained in the present study (in bold). Numbers at nodes indicate bootstrap values greater than or equal to $50 \%$ for distance and parsimony analyses. Scale bar 0.02 substitutions per nucleotide position. GeneBank sequence accession numbers are given in parentheses. 


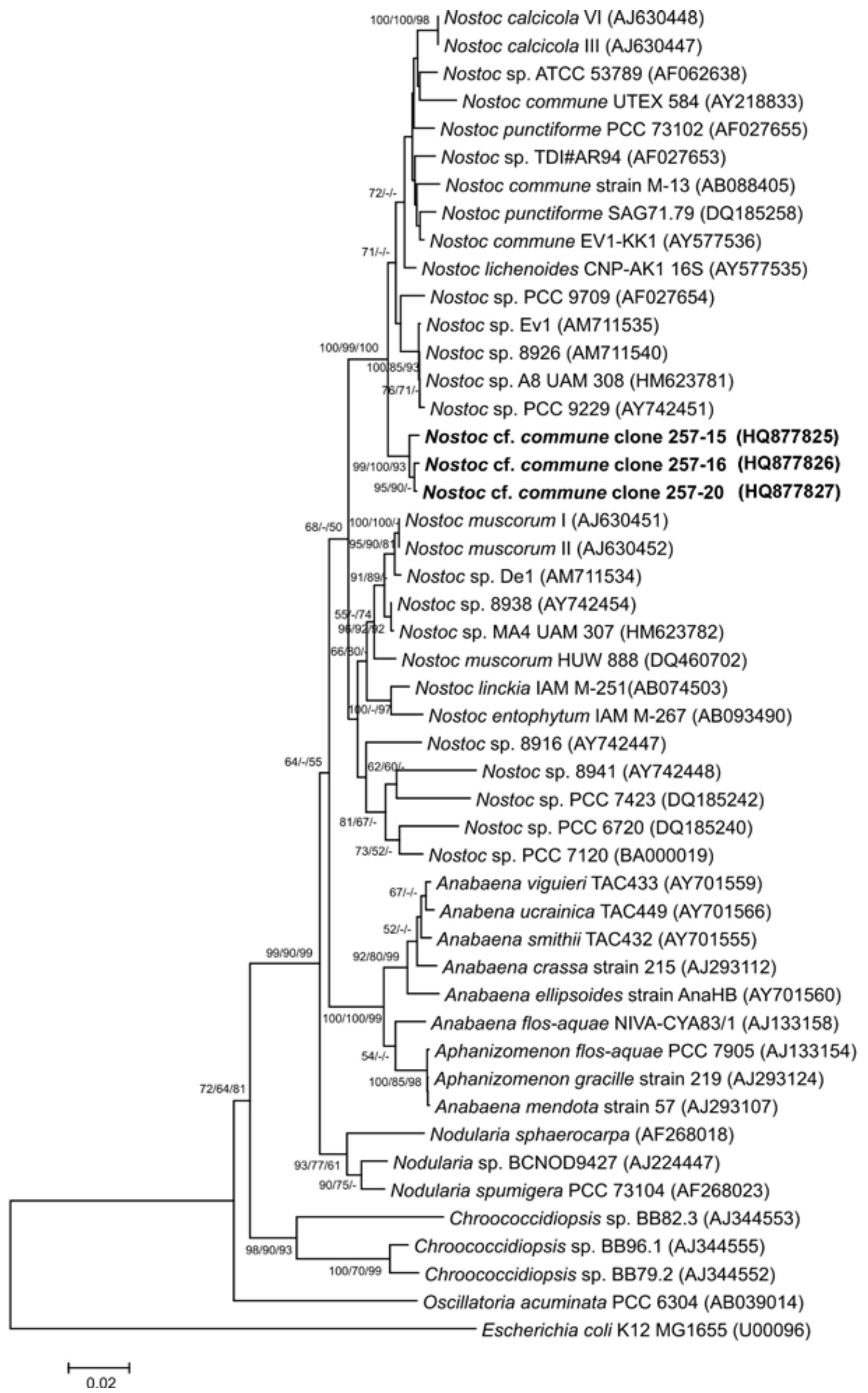




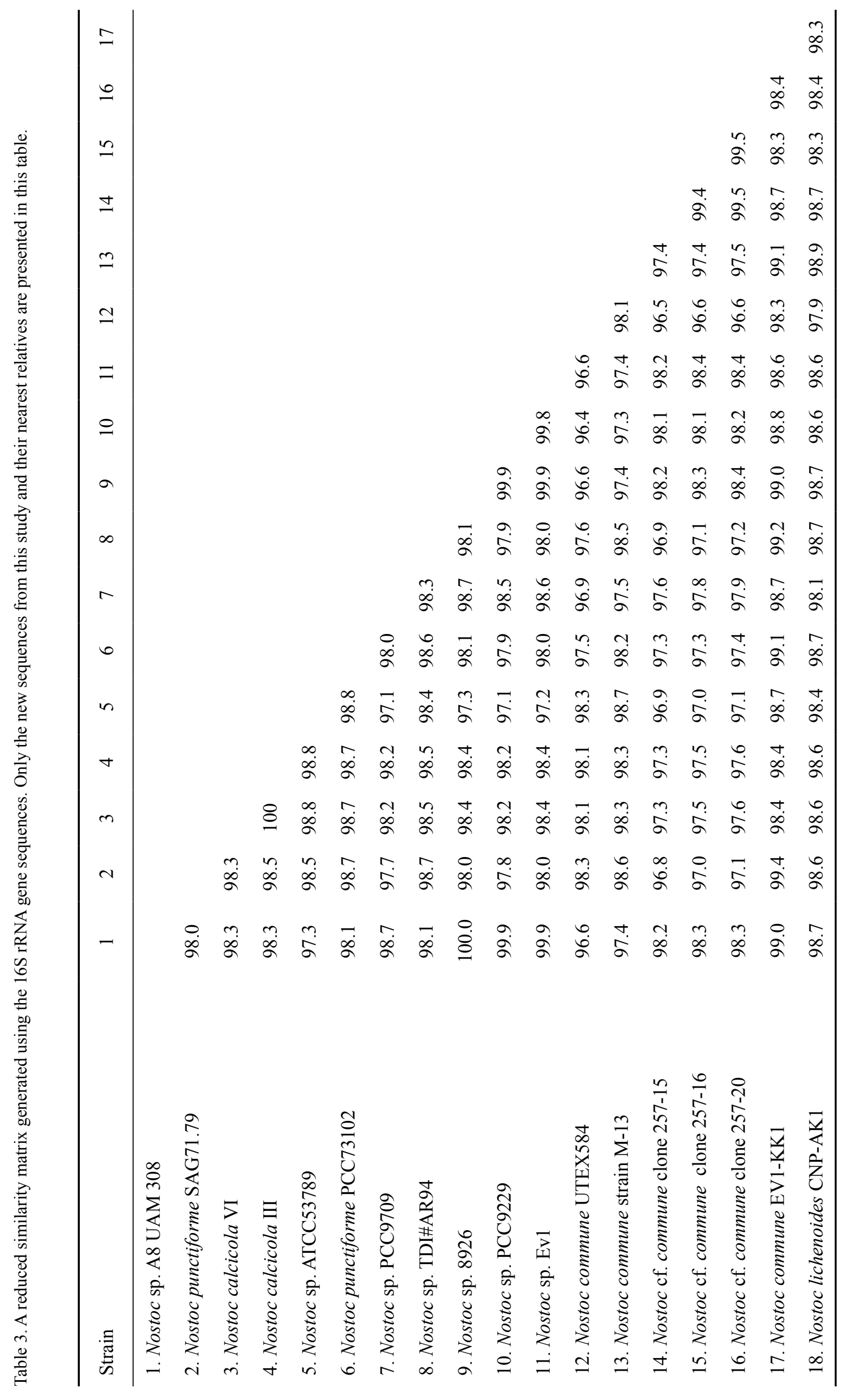


light. However, PE - the synthesis of which poses a considerable metabolic cost for cells (ARÁOZ \& HÄDER 1999) — was only synthetized in the lightintensive, drought conditions of Site II, during the dry season.

The distribution of thylakoids in Nostocales is stable (KOMÁREK \& ANAGNOSTIDIS 1989). However, the increase in cell volume that accompanies the transition from hormogonia to full-developed vegetative cells implies larger photosynthetic membranes, which expand from the periphery of the hormogonia to fill nearly all of the cell lumen in old aseriate cells or akinetes, where the only gaps are occupied by nucleoid material and carboxisomes. These variations, clearly seen in the TEM micrographs, apparently induced a shift in the localization of the fluorescence signal in the CLSM images: in post-hormogonia, the signal was parietal, but in mature vegetative cells, it was evenly distributed throughout the cell. Intercellular connections between vegetative cells have been observed by conventional TEM and freeze fracture replica in the genus Nostoc (Gorelova \& Baulina 2009) and it has been suggested that they are structures for intercellular communication (GoRELOVA \& Baulina 2009; Flores \& Herrero 2010).

The sequences obtained indicated that our samples belong to a Nostoc sensu stricto clade, which contains strains identified as $N$. commune and N. punctiforme PCC 73102 and terrestrial representatives of Nostoc (Novis \& SMisSEN 2006; ŘEHÁKovÁ et al. 2007), together with two strains of $N$. calcicola (HrouzeK et al. 2005; RAJANIEMI et al. 2005; Papaefthimiou et al. 2008). Similar clustering has been found in other Nostoc studies: cluster I of PAPAEFTHIMIOU et al. (2008), cluster A of Hrouzek et al. (2005), and cluster A of Mateo et al. (in press). However, sequence similarity of $96.4-100 \%$ found between the components of the cluster indicates high genetic divergence regarding components of this group. DNA-DNA homology studies have been used to measure the degree of relatedness between organisms with high 16S rRNA sequence similarity. StaCKEBRANDT \& Goebel (1994) suggested a threshold of $97 \%$ 16S rRNA gene sequence similarity to separate species, on the grounds of when two strains have genetic identity below $97.5 \%$, they consistently have DNA-DNA hybridization values below $70 \%$, which has been used as a criterion for recognizing bacterial species (WAYNE et al.1987). Our sequences had $98.3-98.7 \%$ similarity with $N$. commune EV1-KK1 isolated from a cement basin in České Budějovice, Czech Republic, and whose identity as that taxon was confirmed by Dr. JIŘi Komárek (Academy of Science, Třeboň, Czech Republic) ( ̌̌EHÁKOvÁ et al. 2007). According to this threshold these sequences may be from the same genospecies. However, more recently, STACKEBRANDT \& EBERs (2006) suggested an increase from 97.0 to $98.7-99.0 \% 16 \mathrm{~S}$ rRNA gene sequence similarity for the threshold to delineate separate species, which is at the borderline for our sequences. DNA-DNAhybridization studies could confirm species identity. The fact that akinetes able to develop into hormogonia were very abundant in culture but were only scarce in the field, combined with discrepancies in molecular criteria, suggested that the cultured material might not actually be $N$. commune. Nevertheless, the field material was ruled out as being $N$. punctiforme, based on colony morphology: $N$. punctiforme forms punctiforme masses of closely appresed cells and features akinetes that divide without forming filaments (KANTZ \& Bold 1969). Moreover, $N$. punctiforme may not have the capacity to tolerate dessication cycles (Meers et al. 2001) as much as $N$. cf. commune.

Nostoc species are common in biofilms on ancient Mayan buildings in Mexico (GAYLARDE et al. 2001; RAmírez et al. 2010). The distribution and success of Nostoc cf. commune in Bonampak (Chiapas, Mexico) comes as a result of its environmental plasticity, such as the resistant stages and the changes in pigment composition.

\section{Acknowledgements}

The authors are indebted to Servei de Microscopia, Universitat Autònoma de Barcelona and to Serveis Cientificotècnics (SCT), Universitat de Barcelona. Mónica Ramirez was supported by Programme Alßan (scholarship No. E06D100109MX), a European Union program for high level scholarships for Latin America. The authors thank Instituto Nacional de Antropología e Historia (INAH).

\section{References}

Abdelahad, N. \& Bazzichelli, G. (1989): Ultrastructure and development of "coccoid cells" of Nostoc commune (Cyanophyta). - Br. Phycol. J. 24: 217-222.

ArÁoz, R. \& HÄDER, D.P. (1999): Phycoerythrin synthesis is induced by solar UV-B in the

cyanobacterium Nostoc. - Plant Physiol. Biochem. 37: 
$223-229$.

Berrendero, E., Perona, E. \& Mateo, P. (2008): Genetic and morphological characterization of Rivularia and Calothrix (Nostocales, Cyanobacteria) from running water. - Int. J. Syst. Evol. Microbiol. 58: 447-460.

Billi, D. \& Potts, M. (2002): Life and death of dried prokaryotes. - Res. Microbiol. 153: 7-12.

Bordowitz, J.R. \& MontGomery, B.L. (2010): Exploiting the autofluorescent properties of photosynthetic pigments for analysis of pigmentation and morphology in live Fremyella diplosiphon cells. - Sensors 10: 6969-6979.

Boyer, S.L., Flechtner, V.R. \& Johansen, J.R. (2001): Is the $16 \mathrm{~S}-23 \mathrm{~S}$ rRNA internal transcribed spacer region a good tool for use in molecular systematics and population genetics? A case study in cyanobacteria. - Mol. Biol. Evol. 18: 1057-1069.

Dodds, W.K., Gudder, D.A. \& Mollenhauer D. (1995): The ecology of Nostoc. - J. Phycol. 31: $2-18$.

Edwards, U., Rogall, T., Blockerl, H., Emde, M. \& BotTGER, E.C. (1989): Isolation and direct complete nucleotide determination of entire genes. Characterization of a gene coding for 16S ribosomal RNA. - Nucleic Acids Res. 17: 7843-7853.

Ehling-Schulz, M., Bilger, W. \& Scherer, S. (1997): UVB induced synthesis of photoprotective pigments and extracellular polysaccharides in the terrestrial cyanobacterium Nostoc commune. - J. Bacteriol. 179: 1940-1945.

Flores, A. \& Herrero, A. (2010): Compartmentalized function through cell differentiation in filamentous cyanobacteria. - Nature Reviews Microbiology 8: 39-50.

Fremy, P. 1930. Les Myxophycées de l'Afrique Equatoriale Française. Arch. Bot. - Caen. Mem. 3: 1-508.

Fukuda, S., Yamakawa, R., Manabu, H., Yasuhiro, K., Koike, H. \& SAtoh, K. (2008): Mechanisms to avoid photoinhibition in a desiccation-tolerant cyanobacterium Nostoc commune. - Plant Cell Physiol. 49: 488-492.

Gaylarde, P.M., Gaylarde, C.C., Guiamet, P.S., Gomez de Saravia, S.G. \& Videla, H.A. (2001): Biodeterioration of Mayan buildings at Uxmal and Tulum, Mexico. - Biofouling 17: 41-45.

Garcia-Pichel, F. \& Castenholz, R.W. (1991): Characterization and biological implications of scytonemin, a cyanobacterial sheath pigment. - J. Phycol. 27: 395-409.

Geitler, L. (1932): Cyanophyceae. - In: Rabenhorst‘s Kryptogamenflora, 14. - 1196 pp., Akad. Verlagsges, Leipzig.

Gkelis, S., Rajaniemi, P., Vardaka, E., MoustakaGouni, M., Lanaras, T. \& Sivonen, K. (2005):
Limnothrix redekei (Van Goor) Meffert (Cyanobacteria) strains from Lake Kastoria, Greece form a separate phylogenetic group. Microb. Ecol. 49: 176-82

Gorelova, O.A. \& Baulina, O.I. (2009): Ultrastructure of cyanobacterium Nostoc sp. f. Blasia cell forms in persisting populations. - Microbiology 78: 609-617.

Guindon, S. \& Gascuel, O. (2003): A simple, fast, and accurate algorithm to estimate large phylogenies by maximum likelihood. - Syst. Biol. 52: 696704.

HaLl, T. A. (1999): BioEdit: a user-friendly biological sequence alignment editor and analysis program for Windows 95/98/NT. - Nucleic Acids Symp. Ser. 41: 95-98.

Hill, D.R., Keenan, T.W., Helm, R.F., Potts, M., Crowe, L.M. \& Crowe J.H. (1997): Extracellular polysaccharide of Nostoc commune (Cyanobacteria) inhibits fusion of membrane vesicles during desiccation. - J. Appl. Phycol. 9: 237-248.

Hirai, M., Yamakawa, R., Nishio, J., Yamaji, T., Kashino, Y., KoIKe, H., SATOH, K. (2004): Deactivation of photosynthetic activities is triggered by loss of a small amount of water in a desiccation-tolerant cyanobacterium, Nostoc commune. - Plant Cell Physiol. 45: 872-878.

Hrouzek, P., Ventura, S., Lukešová, A., Mugnai, M.A., Turicchia, S. \& KomÁrek, J. (2005): Diversity of soil Nostoc strains: phylogenetic and morphological variability.- Algological Studies 117: 251-264.

Kantz, T. \& Bold. H.C. (1969): Phycological Studies. IX. Morphological and taxonomic investigations of Nostoc and Anabaena in culture. University of Texas Publication no. 6924. - 67 pp., University of Texas Press, Austin.

Keränen, M., Aro, E. \& Tyystuärvi, E. (1999): Excitation-emission map as a tool in studies of photosynthetic pigment-protein complexes. Photosynthetica 37: 225-237.

KomÁReK, J. (2010): Modern taxonomic revision of planktic nostocacean cyanobacteria: a short review of genera. - Hydrobiologia 639: 231243.

KomÁreK, J. \& K. Anagnostidis (1989): Modern approach to the classification system of cyanophytes. 4. Nostocales. -Algological Studies 56: 247-345.

Kumar, D. \& Murthy, S. (2007): Photoinhibition induced alterations in energy transfer process in phycobilisomes of PSII in the cyanobacterium, Spirulina platensis. - J. Biochem. \& Mol. Biol. 40: 664-648.

Lepère, C., Wilmotte, A. \& Meyer, B. (2000): Molecular Diversity of Microcystis strains (Cyanophyceae, Chroococcales) based on 16S 
rDNA sequences. - Systematics and Geography of Plants 70: 275-283.

Mateo, P., Perona, E., Berrendero, E., Leganés, F., Martín, M. \& Golubić, S. Life cycle as stable trait in the evaluation of diversity of Nostoc from biofilms in rivers. - FEMS Microbiol. Ecol. (in press)

Meeks, J.C. \& Elhai, J. (2002): Regulation of cellular differentiation in filamentous cyanobacteria in free- living and plant-associated symbiotic growth states. - Microbiol. Mol. Biol. Rev. 66: 94-121.

Millie, D.F., Schofield, O.M.E., KirkPatrick, G.J., Johnsen, G. \& Evens, T.J. (2002): Using absorbance and fluorescence spectra to discriminate microalgae. - Eur. J. Phycol. 37: 313-322.

Mollenhauer, D. (1988): Nostoc species in the field. Algological Studies 50-53: 315-326.

Mollenhauer, D., Büdel, B. \& Mollenhauer, R. (1994): Approaches to species delimitations in the genus Nostoc Vaucher 1803 ex Bornet et Flahault 1888. - Algological Studies 75: 189209.

Novis, P.M. \& Smissen, R.D. (2006): Two genetic and ecological groups of Nostoc commune in Victoria Land, Antarctica, revealed by AFLP analysis. - Antarct. Sci. 18: 573-581.

ONG, L.J. \& Glazer, A.N. (1988): Structural studies of phycobiliproteins in unicellular marine cyanobacteria. - In: Stevens, S.E. Jr \&. BRYANT, D.A. (eds.): Light-Energy Transduction in Photosynthesis: Higher Plant and Bacterial Models. - pp.102-121, American Society of Plant Physiologists, Rockville, MD, USA.

Papaefthimiou, D., Hrouzek, P., Mugnai, M.A., Lukesova, A., Turicchia, S., Rasmussen, U. \& Ventura, S. (2008): Differential patterns of evolution and distribution of the symbiotic behaviour in nostocacean cyanobacteria. - Int. J. Syst. Evol. Microbiol. 58: 553-564.

PeAt, A. \& Potts, M. (1987): The ultrastructure of immobilised desiccated cells of the cyanobacterium Nostoc commune UTEX 584. FEMS Microbiol. Letters 43: 223-227.

Potтs, M. (2000): Chapter 17: Nostoc. - In: Whitton, B.A. \& PotTs, M. (eds): The ecology of cyanobacteria.-pp. 465-504. Kluwer Academic Publishers, Dordrecht, Netherlands.

Ramírez, M., Hernández-Mariné, M., Novelo, E. \& RoldÁn, M. (2010): Cyanobacteria-containing biofilms from a Mayan monument in Palenque, Mexico. - Biofouling 26: 399-409.

Rajaniemi, P., Hrouzek, P., Kaštovská, K., Willame, R., Rantala, A., Hoffmann, L., Komárek, J. \& Sivonen, K. (2005): Phylogenetic and morphological evaluation of the genera Anabaena, Aphanizomenon, Trichormus and
Nostoc (Nostocales, Cyanobacteria). - Int. J. Syst. Evol. Microbiol. 55: 11-26.

Řeháková, K., Johansen, J.R., Casamatta, D.A., Xuesong, L. \& Vincent, J. (2007): Morphological and molecular characterization of selected desert soil cyanobacteria: three species new to science including Mojavia pulchra gen. et sp. nov. - Phycologia 46: 481-502.

Roldán, M., Clavero, E., Castel, S. \& HernándezMARINÉ, M. (2004a): Biofilms fluorescence and image analysis in hypogean monuments research. - Algological Studies 111: 127-143.

Roldán, M., Thomas, F., Castel, S., Quesada, A. \& HernándeZ-Mariné, M. (2004b): Non invasive pigment identification in single-cells from living phototrophic biofilms by confocal imaging spectrofluorometry. - Appl. Environ. Microbiol. 70: 3745-3750.

Roldán, M., Oliva, F., González del Valle, M. A., SAIZ-JimENEZ, C., \& HERNÁNDEZ-MARINÉ, M. (2006): Does green light influence the fluorescence properties and structure of phototrophic biofilms?. - Appl. Environ. Microbiol. 72: 3026-3031.

SAitou, N. \& NeI, M. (1987): The neighbor-joining method: a new method for reconstructing phylogenetic trees. - Mol. Biol. Evol. 4: 406425.

Sakamoto, T., Yoshida, T., Arima, H., Hatanaka, Y., TAKANI, Y. \& TAMARU, Y. (2009). Accumulation of trehalose in response to desiccation and salt stress in the terrestrial cyanobacterium Nostoc commune. - Phycological Research 57: 66-73.

Satoh, K., Hirai, M., Nishio, J., Yamaji, T., Kashino, Y. \& KoIKe, H. (2002): Recovery of Photosynthetic Systems during Rewetting is Quite Rapid in a Terrestrial Cyanobacterium, Nostoc commune.Plant Cell Physiol. 43: 170-176.

Stackebrandt, E. \& Goebel, B.M. (1994): Taxonomic note: a place for DNA-DNA reassociation and $16 \mathrm{~S}$ rRNA sequence analysis in the present species definition in Bacteriology.- Int. J. Syst. Bacteriol. 44: 846-849.

Stackebrandt, E. \& Ebers, J. (2006): Taxonomic parameters revisited: tarnished gold standards. - Microbiol. Today 33: 152-155.

Stanier, R. Y., Kunisawa, R., Mandel, R. \& CohenBAzIre, G. (1971): Purification and properties of unicellular blue-green algae (Order Chroococcales). - Bacteriol. Rev. 35: 171-205.

Strasser, R. J. \& Butler, W.L. (1977): Fluorescence emission spectra of Photosystem I, Photosystem II and the light-harvesting chlorophyll $\mathrm{a} / \mathrm{b}$ complex of higher plants. - Biochim. Biophys. Acta 462: 307-313.

Tajima, F. \& NeI, M. (1984): Estimation of evolutionary distance between nucleotide sequences. - Mol. Biol. Evol. 1: 269-285. 
Tamaru, Y., Takani, Y., Yoshida, T. \& SaKamoto, T. (2005): Crucial role of extracellular polysaccharides in desiccation and freezing tolerance in the terrestrial cyanobacterium Nostoc commune. - Appl. Environ. Microbiol. 71: 7327-7333.

Tamura, K., Dudley, J., Nei, M. \& Kumar, S. (2007): MEGA4: Molecular Evolutionary Genetics Analysis (MEGA) software version 4.0. - Mol. Biol. Evol. 24: 1596-1599.

Thompson, J.D., Higgins, D.G. \& Gibson, T.J. (1994): CLUSTAL W: Improving the sensitivity of progressive multiple sequence alignment through sequence weighting positions-specific gap penalties and weight matrix choice. Nucleic Acids Res. 22: 4673-4680.

Venugopal, V., Prasanna, R., Sood, A., Jaiswal, P. \& KAUSHIK, B.D. (2006): Stimulation of pigment accumulation in Anabaena azollae strains: effect of light intensity and sugars. - Folia Microbiol. 51: 50-56.

Wayne, L.G., Brenner, D.J., Colwell, R.R., Grimont, P.A.D., Kandler, O., Krichevsky, M.I., Moore, L.H., Moore, W.E.C., Murray, R.G.E., Stackebrandt, E., Starr, M.P. \& Truper, H.G. (1987): Report of the ad-hoc-committee on reconciliation of approaches to bacterial systematics. - Int. J. Syst. Bacteriol. 37: 463464.

Wen, X., Gong, H. \& Lu, C. (2005): Heat stress induces an inhibition of excitation energy transfer from phycobilisomes to Photosystem I in a cyanobacterium Spirulina maxima. - Plant Physiol. Biochem. 43: 389-395.

Wolf, E. \& Schüssler, A. (2005): Phycobiliprotein fluorescence of Nostoc punctiforme changes during the life cycle and chromatic adaptation: characterization by spectral confocal laser scanning microscopy and spectral unmixing. Plant Cell Environ. 28: 480-491.

Wright, D., Prickett, T., Richard, F., Helm, R.F. \& Potтs, M. (2001): Form species Nostoc commune (Cyanobacteria). - Int. J. Syst. Evol. Microbiol. 51: 1839-1852.

(C) Czech Phycological Society (2011)

Recieved Sept 2010

Accepted Dec 2010 